\title{
THE INFLUENCE OF WORK'S MOTIVATION AND COMPENSATION EFFECTS TOWARDS EMPLOYEE'S SATISFACTION, AND THE IMPACT ON THE WORK PERFORMANCE AT STATE EMPLOYEES CIVIL SUB COMPANY, KEBUN JERUK, WEST JAKARTA
}

\author{
Susan Novita Rotua Situmorang, Haryadi Sarjono (haryadisarjono@yahoo.com) \\ Management Department, BINUS University, Jakarta, Indonesia
}

\begin{abstract}
Success in realizing the objectives company relies heavily on existing human resources in organizations in such company. To realize the objectives of the company, the company must consider factors that affect the performance of Civil Servants Work Motivation among others factors, Compensation, and Job Satisfaction. With the achievement of expected performance of Civil Servants Kebon Jeruk District Company can achieve its objectives. Kind research used is descriptive method, Pearson Correlation and Path Analysis is useful to know the response of employees on Work Motivation, Compensation for Job Satisfaction and Their Impacts on Civil Service Performance Kebon Jeruk District Company District Company where the employee population of 60 respondents. Provided the results of a calculation of the structural equation, $Y=0.579 X 1+0.325 X 2+0.644 \varepsilon 1$, where $R 2=0.585$, sub-structure structural equation 2 ie, $Z=0.191 X 1+0.239 X 2+0.618 Y+0.402 \varepsilon 2$ where $R 2=0.838$ Conclusions and Recommendations of this research work motivation (X1) and Compensation (X2) jointly have a significant influence on job satisfaction (Y) equal to $58.8 \%$. Work motivation (X1), Compensation (X2), and Job Satisfaction (Y) jointly have a significant influence on the performance of Civil Servants (Z) equal to $83.8 \%$.
\end{abstract}

Keywords: Work's Motivation, Compensation, Employee's satisfaction.

\section{PREFACE}

In these recent years, the goverment agency is considered as an institute that doesn't really good in working. Just eat the out of work payment whereas the performance is zero. So the society assume that all of the people working in goverment agency can't be an accusation place of society. So, that assumption slowly fixed with the existence of the policies that already made by Goverment to get the society trust, give the best service for society, and be a wise leader, responsible in each provinces of DKI Jakarta.

To be survive and develop, office demands skill level and also the responsibility of their employees. But, beside of demanding the working performance of employees, the office also has to pay attention to the job satisfaction for their employees. The more satified the employees, the more productive, dicipline, and loyal those employees with the company, so it easier in achieve the company goal. Related to those problems, the main problems that will be researched are : 1) How big the contribution of work motivation and compensation simultaneously and partially to the job satisfaction on Kantor Kecamatan Kebon Jeruk, 2) How big the contribution of work motivation, compensation, and job satisfaction of the employees simultaneously and partially to the work performance of civil servants on Kantor Kecamatan Kebon Jeruk?

Researh Purposes

1). To get to know the contribution of work motivation and compensation simultaneously and partially to the job satisfaction on Kantor Kecamatan Kebon Jeruk. (T-1), 2) To get to know the contribution of work motivation, compensation, and job satisfaction of the employees simultaneously and partially to the work performance of civil servants on Kantor Kecamatan Kebon Jeruk. (T-2) 


\section{LITERATURE REVIEW}

The Definition of Job Satisfaction

According to Winardi $(2007$, p.1), motivation means "motivate". Motivation is the result of some processes which character is internal or external for an individual who causes the existence of enthusiasm in doing certain activities. While, job motivation is a potential strength in a human that can be developed by him/herself or by some external force that essentially is about monetary and non-monetary rewards, that can influence the performance result in positive or negative way, depend on the situation and condition that faced by that person. According to As'ad (2002, p.45) job motivation is a thing that can create enthusiasm or boost employment. So that, motivation usually called as a booster employment.

\section{Job Motivation Purposes}

According to Hasibuan (2009, p.146), the purposes of Job Motivation are :

1. Increases morality and the employee job satisfaction

2. Increases employee disciplinary

3. Streamlines the staff procurement

4. Creates a great ambiance and employment relation

5. Increases the loyalty, creativity, and employees participation

6. Increases the employee benefit

7. Increases the sense of responsibility of employees to their assignments

The Dimension of Job Motivation

According to Sutrisno Edy $(2009$, p.124), the dimension od job motivation is divided into two:

a. Internal Factor: The willing to be live, appreciation, self esteem.

b. External Factor : The condition of working environment (bright enough, clean, strategic), job security.

The Definition of Compensation

According to Hasibuan $(2009$, p.118), Compensation is all of the income in money, direct or indirect goods that is received by the employee as a service return which is given by the company. The company wants the compensation that is given get more job performance for the employees. Salary is logrolling in money form that paid periodically to the permanent employee and has a certain guarantee. It means, salary will be paid even if the employee not attends. Payment is logrolling that paid to the daily worker who oriented to the agreement that have already accepted by the payer before.

The Purposes of Motivation
a. Cooperation Relationship
b. Effective procurement
c. Employee Stability
d. Discipline

Kind of Compensation

According to Triton (2007, p.125) explains, compensation that is given to employee based on the characteristic of acceptance can be divided into two kinds, they are : 1) Financial compensation, compensation that is accepted by the employee in money form. Things which included in financial compensations are salary or payment, bonus, medicinal treatment, insurance, and so on which is paid by organization or company, 2) Non-Financial Compensation, compensation that is given by the organization or company to maintain the 
employee in long term. Things which included in non-financial compensation are tourism programme, cafetaria, and place of worship in the office.

Based on the mechanism of its acceptances, compensation can be divided into two kinds: 1) Direct compensation, is the compensation which its acceptance is in direct relationship with job performance, salary and payment, 2) Compensation Equipment or indirect compensation, is the compensation which its acceptance not in direct relationship with job performance. The things are included in indirect compensations are :

a. General protection, such as social security, unemployment, and physical defect

b. Personal protection, such as retired, savings, additional severance, and insurance.

c. Payment while not working, as in training time, off work, sick, vacation, and personal event

d. The subsidy of life cycle in legal aid form, parental care, children care, health programme, and counseling.

The Definition of Job Satisfaction

According to Robbins (2003, p.101) Job Satisfaction is an individual general attitude of their job. According to Siagian (2009, p.295) job satisfaction is a someone's perspective, could be in positive or negative way about his/her job. According to T. Hani (2001, p.103-194) Job Satisfaction is an emotional condition, could be pleasing or displeasing in how the employees look at their job. Job satisfaction reflects someone's feeling about their job.

The Dimension of Job Satisfaction

Dimension that determine the Job Satisfaction Dimensi according to Robbins (2003, p.149150), are:

a) The Job that mentally challenged. The employees tended to like the job that gives them a chance to use skill and ability that they have, offering some assignments, freedom, and feedback about how well they have worked. This characteristic makes the job challenging. The less challenging job will create boredom, but the one which too much challenging will create frustration and failed feeling. In an average challenge condition, most of employee will be in happiness and satisfied.

b) An supportive job condition. Employees care about the work environment for individual convenience and to get easier in doing the assignments well, such as an comfort and save working physical condition, providing education and training for the employees to get easier in doing their assignments well.

c) Supportive team work. For most employee, job also fill their needs of social interaction. So that, it's not shocking if having a friendly and supportive team work will raise the job satisfaction. The leader attitude also can be a main determinant of the satisfaction.

The Definition of Employee Job Performance

Maluyu S.P. Hasibuan (2009, p.34) says job performance is a working result that achieved by someone in doing assignments that given to him/her whice is based on the ability, experience, willingness, and time. According to Sutrisno Edy $(2009$, p.164) Job Performance is the result of someone's effort that determined by his/her individual characteristic skill, and the perception of his/her role in that job. Basically, the job performance of the employee is a level of how far the someone's success in doing his/her assignment. It named level of performance by Vroom (on As'ad, 2001).

The Purposes of The Evaluation of Employee's Job Performance

According to Sutrisno Edy $(2009$, p.168) the evaluation of employee job performance is a formal process to do an observation of someone's job performance result periodically. The 
evaluation of employee job performance process is for understanding someone's job performance. This purpose needs a process, that is a set of activity that interrelated.

The Dimension of Employee Job Performance

Based on the regulation of the regional secretary of DKI Jakarta number 1, 2009, Implementation guidance of Government's regulation number 215, 2009 about the subsidy of region performance on Chapter 4 Section 6, about the Private Servants performance, consist of:

1. BHU (Badan Hasil Utama/ The Main Outcome Corporation)

a. The Punctuality of job completion

b. The validity of Job Result

c. The punctuality and the validity in processing and submitting the report on the implementation task.

d. Create employment report early month.

2. BPU (Badan Perilaku Utama/ The Primary Behavior Corporation)

a. The Punctuality in submitting data and information in task.

Frame Work

b. The ability to work together in teamwork.

c. Leadership

Based on the theories that existence so, it could be formulated as a design of frame work that will be used on this research, they are :

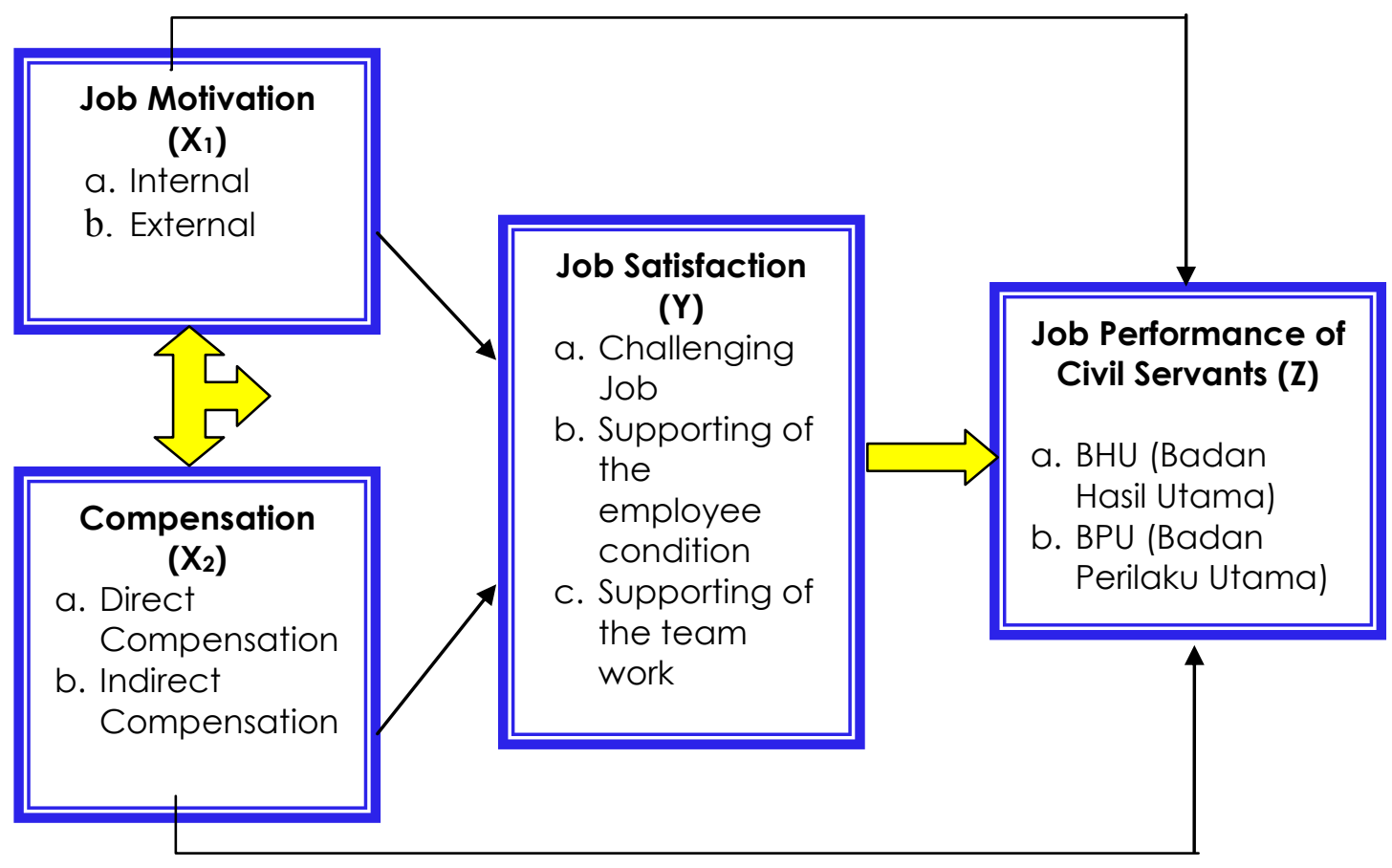

Source: The Writer (2010)

Figure 1. Frame Work

Explanation :

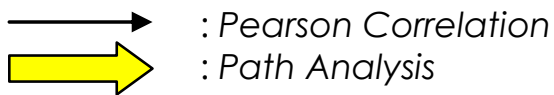




\section{RESEARCH METHOD}

This type of research is associative. With this associative research can be known independent variables influence the dependent variable. In the execution of the research, method was survey. The intended unit of analysis is the individual, namely the private servants Kebon Jeruk District Office and the information on to the employees collected only once at a specified time or also known as cross sectional.

Table 1. Research Design

\begin{tabular}{|c|c|c|c|c|}
\hline \multirow{2}{*}{$\begin{array}{c}\text { Research } \\
\text { Purposes }\end{array}$} & \multicolumn{4}{|c|}{ Research Design } \\
\cline { 2 - 5 } & $\begin{array}{c}\text { Types of } \\
\text { Research }\end{array}$ & $\begin{array}{c}\text { Research } \\
\text { Methods }\end{array}$ & $\begin{array}{c}\text { The Unit of } \\
\text { Analysis }\end{array}$ & $\begin{array}{c}\text { Time } \\
\text { Horizon }\end{array}$ \\
\hline T-1 & Associative & Survey & $\begin{array}{c}\text { Individual- } \\
\text { employee }\end{array}$ & $\begin{array}{c}\text { cross } \\
\text { sectional }\end{array}$ \\
\hline T-2 & Associative & Survey & $\begin{array}{c}\text { Individual- } \\
\text { employee }\end{array}$ & $\begin{array}{c}\text { cross } \\
\text { sectional }\end{array}$ \\
\hline
\end{tabular}

Source : Writer (2010)

Types and Sources of Data

In this research, the data that used is primary data that is kind of data is quantitative data obtained from distributing questionnarires to employees of Kebun Jeruk District Office.

Table 2. Types and Sources of the Research Data

\begin{tabular}{|c|c|c|c|}
\hline Purposes & Data & Types of Data & $\begin{array}{c}\text { Sources of } \\
\text { Data }\end{array}$ \\
\hline T-1 & $\begin{array}{c}\text { Job Motivation, compensation, } \\
\text { toward job satisfaction, }\end{array}$ & Quantitative & $\begin{array}{c}\text { Primer - } \\
\text { questionnaire }\end{array}$ \\
\hline T-2 & $\begin{array}{c}\text { Job Motivation, compensation, } \\
\text { and job satisfaction toward the } \\
\text { job performance of the civil } \\
\text { servants }\end{array}$ & Quantitative & $\begin{array}{c}\text { Primer - } \\
\text { questionnaire }\end{array}$ \\
\hline
\end{tabular}

Source : Research Data (2010)

Data Collection Techniques

To get the data to be processed, the data collection techniques that has done by the author in this research are as follows: 1) Study of literature /(Library Research), 2) Research Field / (Field Research), divided over observation, that is directly observation to the field and questionnaire, namely the list of questions using a scale of measurement.

\section{Data Collection Techniques}

According to Supranto (2000, p.22), in statistics there are two ways of collecting data, namely the census and sampling technique. The census is collecting data in which all elements of the population are investigated one by one. There are two reasons for doing a census: (1) A census study will be worth it if the population is relatively small and (2) a census study is only required when the unit is very varied elements of population (Hermawan, 2005, p147). Based on the reasons put forward by Hermawan, then this research used census, by taking all the existing population, because its population is relatively small. The population in this study are all civil servants of Kebon Jeruk District Office, amounting to 60 people. 
Table 3. Analysis Methods Based on the Research Purposes

\begin{tabular}{|c|c|}
\hline Purposes & Analysis Tools \\
\hline T-1 & $\begin{array}{c}\text { Path Analysis and Pearson } \\
\text { Correlation }\end{array}$ \\
\hline T-2 & $\begin{array}{c}\text { Path Analysis and Pearson } \\
\text { Correlation }\end{array}$ \\
\hline
\end{tabular}

Source : The Result of Data Processing (2010)

Path Analysis

There are several definitions of this path analysis, including: "path analysis is a technique to analyze the causal relations that occur in multiple regression when the independent variables affect the dependent variable not only directly but also indirectly." (Robert D. Retherford 1993). Meanwhile, another definition says: "Path analysis is a direct development of multiple regression in order to give an estimate of importance (magnitude) and significance (significance) hypothetical causal relations in a set of variables." (Paul Webley 1997)

Assumption of path analysis following the general assumption of linear regression, namely:

a. Regression model should be feasible. Feasibility is known if the figure of significance in ANOVA at $<0.05$

b. Predictor is used as a free variable must be feasible. Feasibility is known if the digit Standard Error of Estimate <Standard Deviation

c. Regression coefficient should be significant. Tests performed by test T. Significant regression coefficient if T count> t table (critical value)

d. Multicollinearity should not happen, means that very high correlation should not happen, or very low between the free variable.

e. There were no autocorrelation. Autocorrelation occurs when the figure Dubin and Watson of $<1$ and $>3$.

Variable to test the design of this hypothesis are:

$\mathrm{X} 1=$ Work Motivation

$\mathrm{X} 2=$ Compensation

$Y=$ Job Satisfaction

$Z$ = Performance of Civil Servants

There are two hypotheses to be tested. The hypothesis is as follows:

Hypothesis $1=$ Work Motivation and Compensation simultaneously and partial effect on job satisfaction.

Hypothesis 2 = Work Motivation, Compensation, and Job Satisfaction and partial effect simultaneously on The Performance of Civil Servants

Implications of the Research Result

After all data is finished in processing, then obtained a description of the picture side of the personality of employees in Kebon Jeruk District Office of work motivation factor and Compensation of the job satisfaction and Its Impact on the Performance of Civil Servants Kebon Jeruk District Office and whether Kebon Jeruk District Offices employees already have a high level of Job satisfaction is high, and the extent of Kebon Jeruk District Office achieved the Civil Service Performance if the results showed that the factor of Work Motivation and Compensation, and Its Impact on the Performance of the Civil Service is still low, is necessary to find the cause and organized effort to fix it.

After that, an analysis of data obtained from questionnaires distributed to staff employees Kebon Jeruk District Office, to determine whether work motivation and compensation factors 
have an influence on job satisfaction and Their Impacts on Civil Service Performance Kebon Jeruk District Office. When you get these variables turned out to contribute to job satisfaction at the District Office Kebon Jeruk, it is necessary to attempt to improve the performance of civil servants through these factors, viewed from the aspects, which is an indicator of each variable.

\section{RESULTS AND DISCUSSION}

Sub-structure 1, namely the path analysis of Work Motivation (X1), Compensation (X2) on job satisfaction (Y). The result is as shown by table 4.1, 4.2, and 4.3. Structural equation for the sub-structure 1 are: $Y=\rho_{y \times 1} X_{1}+\rho_{y \times 2} X_{2}+\rho_{y} \varepsilon_{1}$

\section{Table 4. Anova sub-structure 1}

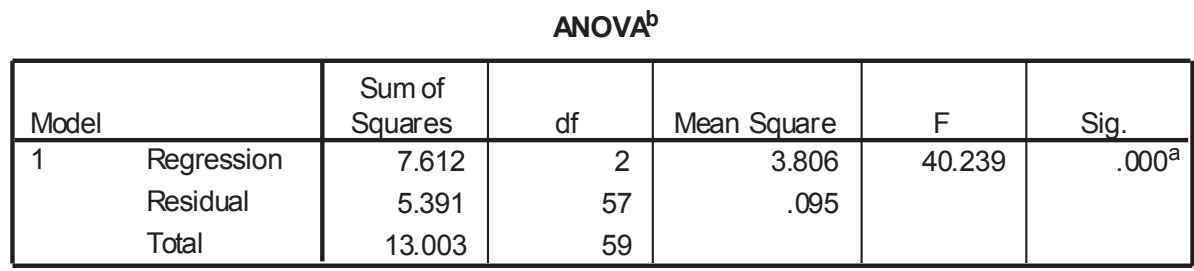

Tabel 5.

Model Summary

\begin{tabular}{|c|c|c|c|c|c|c|c|c|c|}
\hline \multirow[b]{2}{*}{ Model } & \multirow[b]{2}{*}{$\mathrm{R}$} & \multirow[b]{2}{*}{ R Square } & \multirow[b]{2}{*}{$\begin{array}{l}\text { Adjusted } \\
\text { R Square }\end{array}$} & \multirow[b]{2}{*}{$\begin{array}{l}\text { Std. Error of } \\
\text { the Estimate }\end{array}$} & \multicolumn{5}{|c|}{ Change Statistics } \\
\hline & & & & & $\begin{array}{l}\text { R Square } \\
\text { Change }\end{array}$ & F Change & $\mathrm{df} 1$ & $\mathrm{df} 2$ & Sig. F Change \\
\hline 1 & $.765^{\mathrm{a}}$ & .585 & .571 & .30754 & .585 & 40.239 & 2 & 57 & .000 \\
\hline
\end{tabular}

a. Predictors: (Constant), $x 2, x 1$

\section{Model Summary sub-structure 1}

Simultaneously test indicated by Table 4.1

Hypothesis:

$H_{0}$ : Work Motivation and Compensation Variables do not contribute simultaneously and significantly to job satisfaction variables

$H_{a}$ : The quality of service variable and product savings quality simultaneously and significantly contribute to company image variables.

Decision:

From test results in Table 4.2 with $\alpha=0.05$, obtained sig value $=0.000$ so sig value is smaller than $\alpha$ (sig $\leq$ ), that is $0.000 \leq 0.05$. It shows that $H_{0}$ is rejected and $H_{a}$ is accepted. The amount of influence the variables $X 1$ and $X 2$ on $Y$ variables can be identified by looking at the value of $R^{2}$ in Table 4.2. From the table $R^{2}$ value of 0.585 or equal to $58.5 \%$, while the rest equal to $41,5 \%$ influenced by other variables outside the research. Meanwhile, the coefficient paths for other variables outside the research that affect $Y\left(\rho_{y} \varepsilon_{1}\right)$ equal $\sqrt{1-R^{2}}=\sqrt{1-0,585}=$ 0.644

Table 6. Coefficients sub-structure 1

Coefficients $^{\mathrm{a}}$

\begin{tabular}{|c|c|c|c|c|c|c|}
\hline \multirow{2}{*}{\multicolumn{2}{|c|}{ Model }} & \multicolumn{2}{|c|}{$\begin{array}{l}\text { Unstandardized } \\
\text { Coefficients }\end{array}$} & \multirow{2}{*}{$\begin{array}{c}\begin{array}{c}\text { Standardized } \\
\text { Coefficients }\end{array} \\
\text { Beta }\end{array}$} & \multirow[b]{2}{*}{$t$} & \multirow[b]{2}{*}{ Sig. } \\
\hline & & B & Std. Error & & & \\
\hline \multirow[t]{3}{*}{1} & (Constant) & .671 & .288 & & 2.327 & .024 \\
\hline & $\mathrm{x} 1$ & .473 & .075 & .579 & 6.279 & .000 \\
\hline & $x 2$ & .285 & .081 & .325 & 3.527 & .001 \\
\hline
\end{tabular}

a. Dependent Variable: $y$

Source : The Result of Data Processing (2010) 
Based on Table 4.3 obtained sub-structure structural equation $1: Y=0.579 \times 1+0.325 \times 2+$ $0.644 \varepsilon 1$

Analysis of Effect of Work Motivation (X1) and Compensation (X2) on job satisfaction (Y) and Their Impacts on Civil Service Performance

This section will be explained sub-structure 2, which is about the path analysis of Work Motivation $\left(X_{1}\right)$, Compensation $\left(X_{2}\right)$ on job satisfaction $(Y)$ and its Impact on the Performance of Civil Servants (Z). Structural equation for the sub-structure 2 is: $Z=\rho_{z \times 1} X_{1}+\rho_{z \times 2} X_{2}+\rho_{z y} Y+\rho_{z} \varepsilon_{2}$

Table 7. Anova sub-structure 2

ANOVA

\begin{tabular}{|ll|r|r|r|r|l|}
\hline Model & & \multicolumn{1}{|c|}{$\begin{array}{c}\text { Sum of } \\
\text { Squares }\end{array}$} & df & Mean Square & F & Sig. \\
\hline 1 & Regression & 17.014 & 3 & 5.671 & 96.686 & $.000^{\mathrm{a}}$ \\
& Residual & 3.285 & 56 & .059 & & \\
& Total & 20.299 & 59 & & & \\
\hline
\end{tabular}

a. Predictors: (Constant), y, x2, x1

b. Dependent Variable: z

Tabel 8. Model Summary

Model Summary

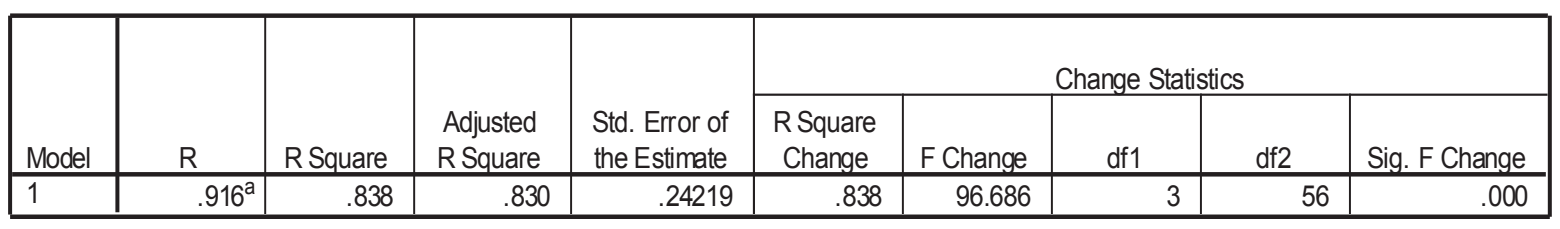

a. Predictors: (Constant), y, X2, x1

Simultaneous testing of variables $\mathrm{X} 1, \mathrm{X} 2$ and $\mathrm{Y}$ with the dependent variable $\mathrm{Z}$

Hypothesis:

$H_{0}$ : Work Motivation Variable, Compensation and Job Satisfaction do not contribute simultaneously and significantly to the performance variable of Civil Servants. $H_{a}$ : Variable Work Motivation, Compensation, and Job Satisfaction contribute simultaneously and significantly to performance variable of Civil Servants.

Decision:

From the significance test results in table 4.5 with $\alpha=0.05$, obtained value $=0.000$ so, sig value is smaller than (sig $\leq \alpha$ ), that is $0.000 \leq 0.05$. It shows that $H_{0}$ is rejected and $H_{a}$ is accepted. The amount of influence the variables $X_{1}, X_{2}$ dan $Y$ to variable $Z$ can be identified by looking at the value of $\mathrm{R} 2$ in Table 5 . From the table $R^{2}$ value is 0.838 or equal to $83.8 \%$, while the remaining $16.2 \%$ is influenced by other variables outside of research. Meanwhile, the coefficient paths for other variables that affect the research outside $Z\left(\rho_{z} \varepsilon_{2}\right)$ equal $\sqrt{1-R^{2}}=\sqrt{1-0,838}=0,402$ 
Tabel 9. Coefficients sub-struktur 2

Coefficients $^{\mathrm{a}}$

\begin{tabular}{|c|c|c|c|c|c|c|}
\hline \multirow{2}{*}{\multicolumn{2}{|c|}{ Model }} & \multicolumn{2}{|c|}{$\begin{array}{l}\text { Unstandardized } \\
\text { Coefficients }\end{array}$} & \multirow{2}{*}{$\begin{array}{c}\begin{array}{c}\text { Standardized } \\
\text { Coefficients }\end{array} \\
\text { Beta }\end{array}$} & \multirow[b]{2}{*}{$\mathrm{t}$} & \multirow[b]{2}{*}{ Sig. } \\
\hline & & B & Std. Error & & & \\
\hline \multirow[t]{4}{*}{1} & (Constant) & -.772 & .238 & & -3.250 & .002 \\
\hline & $\mathrm{x} 1$ & .195 & .077 & .191 & 2.526 & .014 \\
\hline & $x 2$ & .261 & .070 & .239 & 3.721 & .000 \\
\hline & $y$ & .772 & .104 & .618 & 7.406 & .000 \\
\hline
\end{tabular}

a. Dependent Variable: $z$

Based on Table 4.6 the sub-structure structural equation $2: Z=0.191 \times 1+0.239 X 2+0.618 Y+$ $0.402 \varepsilon 2$

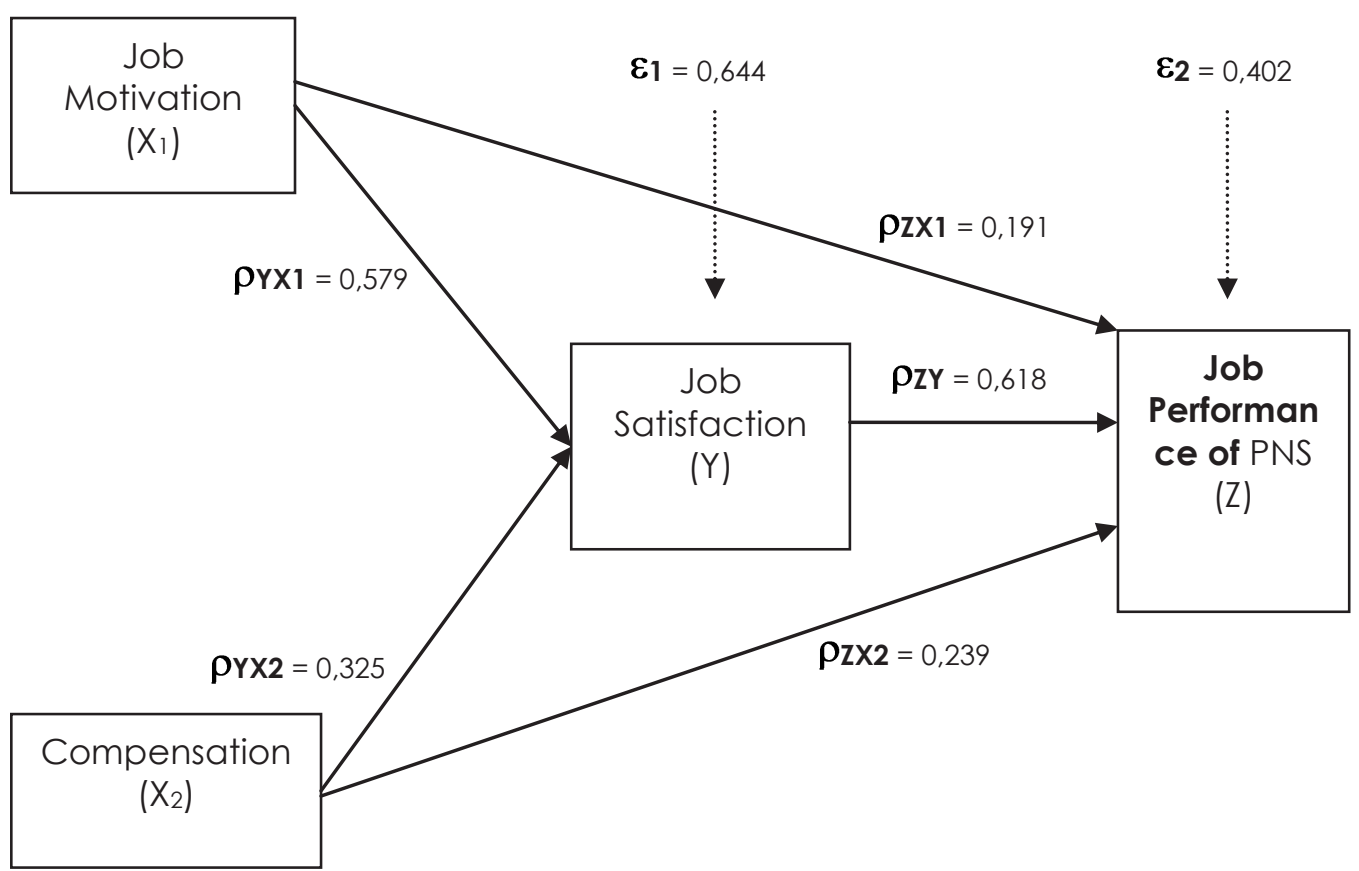

Source : The Result of Data Processing (2010)

Figure 2. Relationship Structure $X_{1}, X_{2}, Y$ and $Z$ with its coefficient of Line

Table 4.7 is to see the direct impact, indirect and total effects among variables based on the results that have been obtained on the analysis of sub-structures 1 and 2 .

Table 10. Path Coefficient Decomposition Summary

\begin{tabular}{|c|c|c|c|c|}
\hline $\begin{array}{c}\text { Effect of } \\
\text { Variable }\end{array}$ & $\begin{array}{c}\text { Path } \\
\text { Coefficient }\end{array}$ & Direct & $\begin{array}{c}\text { Indirect impact } \\
\text { through } \mathbf{Y}\end{array}$ & Total \\
\hline $\mathbf{X}_{1}$ towards $\mathbf{Y}$ & 0,579 & 0,579 & - & 0,579 \\
\hline $\mathbf{X}_{\mathbf{1}}$ towards $\mathbf{Z}$ & 0,191 & 0,191 & $\begin{array}{c}0,579 \times 0,618= \\
0,357\end{array}$ & 0,548 \\
\hline $\mathbf{X}_{\mathbf{2}}$ towards $\mathbf{Y}$ & 0,325 & 0,325 & - & 0,325 \\
\hline $\mathbf{X}_{2}$ towards $\mathbf{Z}$ & 0,329 & 0,329 & $0,325 \times 0,618=$ & 0,529 \\
& & 0,200 & 0,618 \\
\hline $\mathbf{Y}$ towards Z & 0,618 & 0,618 & - & - \\
\hline$\varepsilon_{1}$ & 0,644 & - & - & - \\
\hline $\boldsymbol{\varepsilon}_{2}$ & 0,402 & - & - & \\
\hline
\end{tabular}

Source : The Result of Data Processing (2010) 


\section{CONCLUSION}

1. Work Motivation (X1) and Compensation (X2) simultaneously contribute to job satisfaction (Y) equal to 58.5\%. Where Work Motivation (X1) to contribute to job satisfaction (Y), amounting to 0.579. And Compensation (X2) to contribute to job satisfaction (Y), amounting to 0.325 .

2. Work Motivation (X1), Compensation (X2), and Job satisfaction (Y) simultaneously gives contribution to Performance of Civil Servants (Z) equal to $83.8 \%$. Where Work Motivation (X1) contributed to the Civil Service Performance (Z) of 0.191. Compensation (X2) contributes to the performance of Civil Servants (Z), amounting to 0.239. And Job Satisfaction (Y) contributes to the Civil Servants (Z), amounting to 0.618.

\section{Suggestion}

1. It is better if work motivation is considered and searched some ways to improve employee work motivation by giving job security for all permanent employees in order to measure the employees that work hard and need to be reviewed for each individual of employee that not really work hard by giving training (knowledge) held by the office. Then hold a seminar or workshop about how to improve the personality profile, especially in the work place. In addition, employee that works in Kebon Jeruk also needs to be given an award (indirect compensation) if the work result about monthly report that she/he has made can be justified by giving best employee's. in order to develop the office, so it is needed employee that has a good personality and responsibility, can be seen from motivation work side.

2. It is better if employee's work satisfaction should be one major concern Kebon Jeruk District Office, because it has a huge influence on the achievement of the Civil Service Performance. Office should continue to renew the good working system according to its own employees as well as office and continue to maintain a fair chance of promotion, namely through a system of rewards and punishments, job materials charged to employees, should also be considered to fit the capacity of each individual (not overload) according to the Jakarta administration policy. Kebon Jeruk District Offices will also need to consider implementing a pay rise in accordance with the education and portion of the job for each employee. Office facilities need also to be added and repaired, such as a computer should be upgraded, table and chairs already removed and replaced with a new and renovated office space. By making room for each department head and the head section per division.

\section{DAFTAR PUSTAKA}

As'ad, Mohamad. (2002). Psikologi Industri Seri Ilmu Sumber Daya Manusia. Liberty, Yogyakarta.

Hasibuan, Malau. (2009). Manajemen Sumber Daya Manusia. PT. Bumi Aksara, Jakarta.

Handoko, Hani T dan Reksohadiprojo. (2003) Manajemen Sumber Daya Manusia dan Perusahaan. Edisi Kedua. Yogyakarta: BPFE UGM.

Koesmono, Teman. H. (2005). Pengaruh Budaya Organisasi Terhadap Motivasi Dan Kepuasan Kerja Serta Kinerja Karyawan Pada Sub Sektor Industri Pengolahan Kayu Skala Menengah di Jawa Timur, http://puslit.petra.ac.id/journals/articles.php?PublishedID=MAN05070205, 5 Maret 2010

Kreitner, Robert. Angelo Kinicki. (2005) Perilaku Organisasi 2 (Edisi 5). Jakarta : Salemba Empat.

Notoatmodjo, Soekidjo. (2003). Pengembangan Sumber Daya Manusia. PT. Rineka Cipta, Jakarta.

PB, Triton. (2007). Manajemen Sumber Daya Manusia. Tugu Publisher, Yogyakarta.

Riduwan dan Engkos Achmad Kuncoro. (2008). Cara Menggunakan dan Memakai Analisis Jalur (PATH ANALYSIS) Cetakan ke 2. Alfabeta, Bandung. 
Rivai, Veithzal. (2004). Kepemimpinan dan Perilaku Organisasi Edisi Kedua. PT Rajagrafindo Persada, Jakarta.

Samsul. (2008). Hubungan antara kompensasi, iklim organisasi dan motivasi dengan kepuasan kerja karyawan di lingkungan karyawan Koperasi KODANUA Jakarta, (ONLINE), www.digilib.vi.ac.id/opac/themes/libri2/detail.jsp?id=72981\&lokasi=lokal, 5 Mei 2010

Robbins, Stephen P. Benyamin Molan. (2003). Perilaku Organisasi. Jilid 1. PT. Indeks Gramedia, Jakarta.

Supranto, J. (2001). Statistik, Teori dan Aplikasi; Edisi Keenam Jilid 2. Erlangga, Jakarta.

Sutrisno, Edy. (2009). Sumber Daya Manusia, Cetakan ke 2. 